\title{
Efektivitas Media Flash Cards dalam Meningkatkan Kosakata Bahasa Inggris
}

\author{
Eka Fitriyani, Putri Zulmi Nulanda \\ UIN Sultan Syarif Kasim Riau \\ e-mail: eka.fitriyani07@uin-suska.ac.id
}

\begin{abstract}
English proficiency is important because it gives a positive academic influence. English skills can be seen from the amount of vocabulary a person has. One of the creative efforts in learning to be attractive is using flash cards media. This study aims to determine whether flash cards media can improve the vocabulary of students in primary school. This research used quasiexperimental method with nonequivalent pretest-posttest control group design. The research subjects were 35 second grade students of elementary school, which were divided into two groups namely experimental group and control group. The hypothesis of this research is that there is a difference of vocabulary between experimental group and control group before and after giving flash cards media. The independent sample t-test of the gain score of the experimental group (11.7895) was higher than the control group (3.2500) with the 8,998 and sig t-counts 0.000 ( $p<0.01)$, meaning that there is significant difference between pretest-posttest experimental and control group. It shows that flash cards can improve students' English vocabulary.
\end{abstract}

Keywords: Flash cards media, vocabulary, student in Primary School

\begin{abstract}
Abstrak
Kemampuan berbahasa Inggris penting karena kemampuan ini memberikan pengaruh secara akademis. Kemampuan bahasa Inggris dapat dilihat dari kekayaan kosakata yang dimiliki seseorang. Salah satu upaya kreatif dalam pembelajaran agar menarik yaitu menggunakan media flash cards. Penelitian ini bertujuan untuk mengetahui apakah media flash cards dapat meningkatkan kosakata bahasa Inggris siswa di Sekolah Dasar. Penelitian menggunakan metode kuasi eksperimen dengan desain nonequivalent pretest-posttest control group design. Subjek penelitian adalah 35 siswa kelas II Sekolah Dasar, yang terdiri dari kelompok eksperimen dan kelompok kontrol. Hipotesis penelitian ini adalah ada perbedaan kosakata antara kelompok eksperimen dan kelompok kontrol sebelum dan sesudah pemberian media flash cards. Analisis independent sample t-test dari data gain score kelompok eksperimen (11.7895) lebih tinggi daripada kelompok kontrol (3.2500) dengan nilai t-hitung 8.998 dan sig. 0.000 (p<0.01), artinya terdapat perbedaan yang signifikan antara pretest-posttest kelompok eksperimen dan kontrol. Hal tersebut menunjukkan bahwa flash cards dapat meningkatkan kosakata bahasa Inggris siswa.
\end{abstract}

Kata Kunci: Media flash cards, kosakata bahasa Inggris, siswa Sekolah Dasar

\section{Pendahuluan}

Bahasa Inggris disebut juga bahasa kedua atau second language, karena bahasa Inggris merupakan bahasa sasaran yaitu bahasa yang sengaja dipelajari dengan tujuan tertentu (Brown, 2008). Hal tersebut yang mendasari pertimbangan bahasa Inggris mulai diberikan pada siswa Sekolah Dasar (bsnp-indonesia.org). Permendiknas RI. No 23 tahun 2006 menyatakan bahwa Sekolah Dasar dapat menjadikan bahasa
Inggris sebagai mata pelajaran muatan lokal. Bahasa Inggris merupakan bahasa Internasional dan juga merupakan bahasa pengantar untuk sebagian besar pendidikan primer, sekunder dan tersier bagi anak-anak yang mempelajari bahasa Inggris di usia sekolah (Brown, 2008).

Anak-anak lebih mudah menguasai bahasa kedua dibanding remaja dan dewasa. Siswa-siswa dewasa membuat kemajuan awal yang lebih cepat, tetapi 
kesuksesan akhir dalam penguasaan bahasa kedua tidak pernah sebaik anak-anak (Santrock, 2007). Penjelasan mengenai hal tersebut didasari oleh fakta bahwa terdapat ratusan otot (tenggorokan, pita suara, mulut, lidah dan lain-lain) yang digunakan dalam pengucapan kata-kata, pengendalian otot tingkat tinggi diperlukan untuk meraih kefasihan pada penutur asli sebuah bahasa (Brown, 2008). Menurut Brown (2008) bahasa kedua merupakan bahasa sasaran, bahasa yang sengaja dipelajari untuk tujuan tertentu, seperti untuk mencapai karir yang sukses atau memenuhi persyaratan untuk menguasai bahasa asing. Terdapat periode sensitif mempelajari bahasa, sehingga pengenalan terhadap bahasa sangatlah penting selama masa kanak-kanak belia (Ormrod, 2008).

Adapun tujuan diberikannya pelajaran bahasa Inggris yaitu untuk; (1) mengembangkan kompetensi berkomunikasi dalam bentuk lisan (language accompanying action) dalam konteks sekolah, (2) memiliki kesadaran pentingnya bahasa Inggris untuk meningkatkan daya saing bangsa dalam masyarakat global (bsnpindonesia.org). Pada Kurikulum Tingkat Satuan Pendidikan (KTSP) dan silabus siswa kelas 2 Sekolah Dasar, ditemukan banyak materi bahasa Inggris yang menuntut penguasaan kosakata dalam konteks lingkungan kelas.

Menurut Mohammadnejad, Nikdel dan Oroujlou (2012) kosakata merupakan elemen dasar sebuah bahasa yang digunakan untuk memberi label pada halhal seperti benda, sifat dan kata kerja untuk menjelaskan maksud dari apa yang ingin disampaikan. Khasanah, Chamdani dan Susiani (2014) menyebutkan bahwa dalam proses mempelajari bahasa Inggris, kosakata merupakan bagian penting, namun sering diabaikan dalam kegiatan pembelajaran. Tanpa mengetahui kosakata, siswa akan mengalami hambatan dalam pembelajaran bahasa Inggris. Pembelajaran bahasa Inggris bagi siswa Sekolah Dasar belum didasarkan pada acuan yang jelas dan penyiapan guru yang tepat. Para guru tidak dilatih secara sungguh-sungguh untuk menjadi pengajar bahasa Inggris bagi siswa Sekolah Dasar. Akibatnya, pembelajaran bahasa Inggris di Sekolah Dasar dianggap sebagai beban. Padahal dengan memperkaya metode pengajarannya, para guru bisa dengan mudah menyesuaikan pembelajaran bahasa Inggris dengan kondisi peserta didik (Keswara, 2012).

Hasil wawancara dan observasi yang diperoleh dari guru yang mengajar bidang studi bahasa Inggris di Sekolah " $A$ " terdapat $46 \%$ siswa kelas II yang mencapai KKM (Kriteria Ketuntasan Minimal) bahasa Inggris. Pada Sekolah "B" terdapat $31 \%$ siswa kelas II yang aktif dalam belajar dan yang mencapai KKM hanya $28 \%$ dari jumlah siswa keseluruhan.

Berdasarkan wawancara yang dilakukan pada tanggal 5 dan 6 September 2016 dengan Guru kelas II sekolah "A" dan Kelas II sekolah "B", menyatakan bahwa proses pembelajaran di kelas menggunakan metode ceramah atau latihan soal. Guru hanya memberikan lembar kerja siswa (LKS) dan menginstruksikan pada siswa untuk menyelesaikannya, maka diperlukan perbaikan metode untuk siswa Sekolah Dasar. Pembelajaran bahasa Inggris di sekolah dengan metode ceramah dan latihan soal (teacher active) dinilai masih kurang menyenangkan dan membosankan bagi siswa. Siswa hanya mengerjakan soal-soal yang ada di dalam LKS, lalu dikumpulkan dan dinilai oleh guru kelas tersebut. Metode pengajaran dan SDM (Sumber Daya Manusia) guru menjadi faktor penting penyebab kurang nyamannya pembelajaran bahasa Inggris di Sekolah. Padahal dengan memperkaya metode pengajarannya, para guru bisa dengan mudah menyesuaikan pembelajaran bahasa Inggris dengan kondisi peserta didik (Keswara, 2012). Listyarti (2012), mengatakan bahwa pembelajaran bahasa Inggris untuk tingkat Sekolah Dasar memang harus dibedakan dengan tingkat Sekolah Menengah Pertama dan Sekolah 
Menengah Atas. Menurutnya, anak-anak usia Sekolah Dasar cukup dibekali dengan berbagai kosakata baru dengan cara yang menyenangkan dalam memperkenalkannya.

Menurut Baleghizadeh dan Ashoori (2011) salah satu masalah utama kesulitan yang dialami guru dalam mengajarkan bahasa Inggris pada siswa adalah guru tidak menggunakan metode dan pendekatan yang tepat. Oleh sebab itu, guru bertanggung jawab dalam menentukan pendekatan yang tepat dalam mengajarkan kosakata kepada siswa.

Munurut teori perkembangan kognitif dari Piaget, perkembangan kognitif siswa Sekolah Dasar berada pada fase operasional konkret. Operasional konkret adalah tindakan mental yang bisa dibalikkan yang berkaitan dengan objek konkret nyata. Pada tahap ini anak akan mudah mempelajari sesuatu yang kompleks dengan bantuan visual dan mereka akan tertarik untuk belajar apabila guru dapat menarik perhatian mereka. Dengan memahami tahap perkembangan kognitif siswa dapat membantu guru dalam menentukan metode dan pendekatan mengajar (Santrock, 2010). Menurut Vygotsky, bantuan dapat diberikan oleh siswa dewasa untuk siswa, bantuan yang diberikan tersebut dikenal dengan zone of proximal development (ZPD). ZPD adalah istilah Vygotsky untuk serangkaian tugas yang terlalu sulit dikuasai anak secara sendirian tetapi dapat dipelajari dengan bantuan dari siswa dewasa atau anak yang lebih mampu (Santrock, 2010).

ZPD berkaitan dengan scaffolding, scaffolding adalah sebuah mekanisme pendukung yang membantu siswa pembelajar untuk berhasil menyelesaikan satu tugas dalam zona perkembangan proximal-nya. Guru memberikan beragam bentuk bantuan kepada siswa, dengan cara menyederhanakan tugas, memecahkan tugas menjadi komponen-komponen yang lebih kecil atau memberikan peralatan yang tidak terlalu rumit (Ormrod, 2008).
Suyanto (2010) mengatakan media merupakan alat bantu yang diperlukan untuk pembelajaran bahasa Inggris terutama untuk anak-anak. Kegiatan belajar mengajar bahasa Inggris untuk anak seharusnya disertai dengan penggunaan media, terutama visual. Media adalah segala sesuatu yang dapat digunakan untuk menyalurkan pesan dari pengirim ke penerima sehingga dapat merangsang pikiran, perasaan dan minat serta perhatian siswa sedemikian rupa sehingga proses belajar terjadi (Sadirman, Rahardjo dan Haryono, 2009). Media visual yang dapat diberikan kepada siswa salah satunya adalah media flash cards (Suyanto, 2010)

Flash cards merupakan kartu kecil yang berisi gambar, teks, atau tanda simbol yang mengingatkan atau menuntun siswa kepada sesuatu yang berhubungan dengan gambar-gambar yang dapat digunakan untuk melatih mengeja dan memperkaya kosakata (Arsyad, 2011). Flash cards memiliki dua sisi, bagian depan flash cards terdapat gambar dan kata sedangkan bagian belakang flash cards merupakan arti kata tersebut. Hudson, Taglieber, Johnson dan Yarbrough (dalam Carpenter dan Olson, 2011) mengemukakan bahwa gambar yang terdapat pada flash cards tersebut akan membantu meningkatkan daya ingat anakanak, karena visual memberikan pengaruh yang lebih besar dalam mengingat dan memahami sesuatu dibandingkan verbal/ audio. Paivio (dalam Stephen, 2011), menjelaskan landasan yang menyatakan gambar lebih efektif terhadap memori adalah karena gambar memberikan kode memori lain yang bersifat independen dari kode verbal. Gambar cenderung mudah diingat dibandingkan dengan kata-kata yang bersifat konkret, dan biasanya mudah disimpan dalam memori dibandingkan dengan kata-kata yang bersifat abstrak (Stephen, 2011).

Berdasarkan penelitian yang dilakukan oleh Nugroho, Nurkamto dan Sulistyowati (2012) ditemukan bahwa dengan menggunakan flash cards dapat 
meningkatkan kemampuan kosakata siswa, karena flash crads dapat menarik perhatian siswa, membuat siswa termotivasi dan fokus dalam belajar kosakata. Media flash card dianggap sebagai suatu media yang menimbulkan kesenangan dan ketertarikan siswa dalam pembelajaran kosakata, karena flash card dapat disajikan dalam bentuk permainan (Hotimah, 2010). Brown (2008) mengatakan selain dapat dilakukan dengan cara bermain, flash cards juga dapat digunakan dimanapun diinginkan oleh anak. Selain dapat menciptakan suasana belajar yang menyenangkan flash cards juga merupakan media yang sangat praktis karena dapat dibuat secara bersama-sama oleh guru dan siswa (Baleghizadeh dan Ashoori, 2011). Brown (2008) mengatakan, selain faktor kognitif, faktor afektif juga memengaruhi keberhasilan siswa dalam mempelajari bahasa.

Menurut Komachali dan Khodareza (2012) dengan flash cards siswa dapat belajar tanya jawab seputar kosakata, harihari bersejarah, rumus dan mata pelajaran lainnya. Hal itu dapat dilakukan secara berulang sehingga membuat flash cards membantu siswa mengingat apa yang telah dipelajari.

Adapun tujuan penelitian ini adalah untuk meningkatkan kemampuan kosakata bahasa Inggris siswa Sekolah Dasar, sehingga dapat memberikan bantuan pada sekolah dalam usaha meningkatkan kemampuan kosakata bahasa Inggris siswa.

\section{Pengertian Kosakata}

Dasar dari sebuah bahasa merupakan kosakata, apabila kosakata tidak ada maka tidak pernah ada yang namanya bahasa. Kata "kosakata" merupakan kata yang mewakili secara ringkas dari sejumlah kumpulan kata dalam bahasa (Joklova, 2009). Kosakata merupakan sejumlah kata yang diketahui siswa pada sebuah bahasa. Kosakata terus berkembang sejalan dengan bertambahnya usia yang sangat berguna sebagai alat komunikasi (Komachali dan Khodareza, 2012).
Menurut Mohammadnejad dkk. (2012), kosakata merupakan elemen dasar sebuah bahasa yang mana digunakan untuk memberi label pada hal-hal seperti benda, sifat dan kata kerja untuk menjelaskan maksud dari apa yang ingin disampaikan. Dalam oxford learner's pocket dictionary (2008), menjelaskan bahwa kosakata merupakan; (1) sejumlah kata yang diketahui dan digunakan siswa, (2) sejumlah kata yang digunakan dalam berbahasa, (3) daftar kata yang terdiri dari kata beserta artinya. Menurut Komachali dan Khodareza (2012), kosakata biasanya berkembang dan meningkat pada setiap tingkatan usia, dan secara fundamental berfungsi sebagai alat komunikasi.

Menurut Brown (2008) faktor lain yang menyebabkan anak-anak dapat lebih mudah menguasai bahasa kedua, karena anak-anak memakai bahasa untuk menampilkan konsepsi mereka sebagai sarana berpikir dan untuk menghadirkan dunia mereka. Kemampuan anak untuk mengucapkan bahasa kedua dengan aksen yang benar juga menurun berdasarkan usia. Penurunan tajam terjadi setelah usia 10 hingga 12 tahun (Asher dan Garcia dalam Santrock, 2007). Hal tersebutlah yang mendukung mengenai periode kritis belajar bahasa asing. Menurut Santrock (2007), periode kritis adalah periode waktu yang pasti saat pengalaman-pengalaman tertentu dapat menimbulkan akibat jangka panjang dalam perkembangan. Periode kritis adalah masa-masa ketika pembelajaran mudah dilakukan, dan setelah periode kritis lewat, belajar menjadi sesuatu yang sulit.

Bahasa pertama dan bahasa kedua memiliki definisi yang berbeda, yaitu bahasa pertama merupakan bahasa yang diperoleh anak secara alamiah, di dalamnya ada proses peniruan, pengulangan dan menjadi perilaku menetap. Sedangkan bahasa kedua merupakan bahasa sasaran, yaitu bahasa yang sengaja dipelajari dengan tujuan tertentu, baik untuk pendidikan, karir dan sebagainya. Cara pemerolehan bahasa pertama tidak jauh berbeda dengan 
bahasa kedua yaitu dengan peniruan, pengulangan tetapi ada aspek lain yang memengaruhi yaitu periode kritis.

\section{Pengajaran Kosakata}

Pavicic (dalam Khodashenas, Farahani dan Alishahi, 2014), mengatakan guru seharusnya mencari cara untuk meningkatkan kemampuan siswa dalam mengeksplorasi, menyimpan dan menggunakan sejumlah jenis kosakata dan menciptakan aktivitas dan tugas untuk membantu siswa meningkatkan kosakata mereka dan mengembangkan strategi untuk belajar kosakata. Menurut Komachali dan Khodareza (2012) untuk dapat mengajarkan kosakata secara efektif, guru seharusnya dapat memutuskan dan menentukan metode dan pendekatan yang sesuai dengan usia siswa yang diajarkan karena mengajarkan bahasa Inggris tidak sama dengan cara mengajarkan bahasa Indonesia. Pengajaran kosakata merupakan sebuah tindakan menunjukkan, memperlihatkan atau memberitahu dengan cara yang tepat sesuai dengan usia dan tingkat kemampuan siswa dalam menerima suatu pengajaran, sehingga siswa tersebut paham dan tahu dengan apa yang diajarkan.

Piaget berpendapat bahwa anak sebagai pelajar aktif, sibuk dengan bendabenda yang ada di sekitarnya. Bila siswa tidak dapat melakukan sesuatu, berarti dia belum waktunya mencapai fase perkembangan untuk melakukan itu, sebaliknya Vygotsky lebih menfokuskan pada hubungan sosial yang dapat membantu anak untuk lebih cepat belajar menggunakan bahasa (Santrock, 2010). Guru dapat memberikan beragam bentuk bantuan kepada siswa, dengan cara menyederhanakan tugas, memecahkan tugas menjadi komponen-komponen yang lebih kecil atau memberikan peralatan yang tidak terlalu rumit. Berdasarkan pemikiran Vygotsky interaksi sosial adalah faktor yang memengaruhi kemampuan kognitif anak, dengan landasan interaksi sosial tersebutlah Vygotsky menciptakan metode scaffolding yaitu sebuah bantuan yang diberikan kepada anak untuk dapat menyelesaikan tugas sesuai zona perkembangan proximal-nya.

\section{Media Flash Cards}

Media adalah segala sesuatu yang dapat digunakan untuk menyalurkan pesan dari pengirim kepada penerima sehingga dapat merangsang pikiran, perasaan, perhatian dan minat serta perhatian siswa sedemikian rupa sehingga proses belajar terjadi (Sadiman dkk., 2009).

Flash cards merupakan kartu kecil yang berisi gambar, teks, atau tanda simbol yang mengingatkan atau menuntun siswa kepada sesuatu yang berhubungan dengan gambar-gambar yang dapat digunakan untuk melatih mengeja dan memperkaya kosakata (Arsyad, 2011). Ukuran tulisan dan gambar yang ada di dalam flash cards harus dibuat dengan ukuran yang cukup besar, supaya seluruh anggota kelas dapat melihat konten yang ada di dalam flash cards tersebut (Muhammadnejad dkk., 2012).

Menurut Baleghizadeh dan Ashoori (2011) flash cards merupakan sebuah kartu yang mana terdapat sebuah kata, kalimat atau gambar di dalamnya. Flash cards memiliki dua sisi, bagian depan flash cards terdapat gambar dan kata sedangkan bagian belakang flash cards merupakan arti kata tersebut. Flash cards merupakan media yang sangat praktis karena dapat dibuat secara bersama-sama oleh guru dan siswa.

Menurut Hotimah (2010), flash cards merupakan media yang berbentuk kartu bergambar yang dibuat dengan menggunakan foto atau gambar, pada bagian belakang terdapat keterangan dari gambar yang ada pada flash cards tersebut. Gambar yang terdapat pada flash cards tersebut akan membantu meningkatkan daya ingat anak-anak, karena visual memberikan pengaruh yang lebih besar dalam mengingat dan memahami sesuatu dibandingkan verbal/ audio (Hudson dkk. dalam Carpenter dan Olson, 2011). 
Flash cards adalah media yang praktis untuk membantu siswa dan guru dalam proses belajar mengajar, khususnya dalam mengajarkan siswa flash cards (Nugroho dkk., 2012). Dengan media flash cards dapat dengan mudah membantu siswa merecall kosakata baru yang sedang dipelajari, karena flash cards memiliki dua sisi yaitu kata dan artinya (Khodashenas dkk., 2014). Media flash cards memiliki beberapa kelebihan, sebagaimana yang diungkapkan oleh Susilana dan Riyana (dalam Hotimah, 2010) antara lain mudah dibawa kemana-mana, praktis, mudah diingat, menyenangkan.

Mudah dibawa kemana-mana; yakni dengan ukuran yang kecil flash cards dapat disimpan di tas bahkan di saku, sehingga tidak membutuhkan ruang yang luas, dapat digunakan di mana saja, di kelas ataupun di luar kelas.

Praktis; yakni dilihat dari cara pembuatannya dan penggunaannya, media flash cards sangat praktis, dalam menggunakan media ini guru tidak perlu memiliki keahlian khusus, media ini tidak perlu juga membutuhkan listrik. Jika akan menggunakannya kita tinggal menyusun urutan gambar sesuai dengan keinginan kita, pastikan posisi gambarnya tepat tidak terbalik, dan jika sudah digunakan tinggal disimpan kembali dengan cara diikat atau menggunakan kotak khusus supaya tidak tercecer.

Mudah diingat; kombinasi antara gambar dan teks cukup memudahkan siswa untuk mengenali konsep sesuatu, untuk mengetahui nama sebuah benda dapat dibantu dengan gambarnya, begitu juga sebaliknya untuk mengetahui nama sebuah benda atau konsep dengan melihat huruf atau teksnya.

Menyenangkan; media flash cards dalam penggunaannya dapat melalui permainan. Misalnya siswa secara berlomba-lomba mencari suatu benda atau nama-nama tertentu dari flash cards yang disimpan secara acak, dengan cara berlari siswa berlomba untuk mencari sesuatu perintah.

Flash cards merupakan media yang sangat praktis karena dapat dibuat secara bersama-sama oleh guru dan siswa. Salah satu indikasi bahwa visual imagery memiliki kemungkinan memberikan kode memori yang efektif adalah siswa biasanya lebih mudah dalam mengenali gambar daripada tulisan. Menurut Paivio (dalam Stephen, 2011), alasan mengapa gambar menjadi lebih efektif adalah karena gambar memberikan kode memori lain yang bersifat independen dari kode verbal. Teori tersebut disebut teori pengodean ganda karena teori tersebut dapat digunakan dalam proses pengingatan kembali. Gambar cenderung mudah diingat dibandingkan dengan kata-kata yang bersifat konkret, dan biasanya mudah disimpan dalam memori dibandingkan kata-kata yang bersifat abstrak (Stephen, 2011).

\section{Metode Penelitian}

\section{Desain Penelitian}

Desain yang digunakan pada penelitian ini adalah kuasi eksperimen. Menurut Campbell, Shadish dan Cook (2002) eksperimen kuasi merupakan sebagai eksperimen yang memiliki perlakuan, pengukuran dampak, unit eksperimen, namun tidak menggunakan penugasan acak atau randomize untuk menciptakan pembandingan dalam rangka menyimpulkan perubahan yang disebabkan perlakuan.

Desain eksperimen yang digunakan dalam penelitian ini adalah nonequivalent pretest-posttest control group designs. Desain penelitian ini merupakan sebuah desain penelitian yang membandingkan dua kelompok non-equivalent dan desain yang sesuai untuk penelitian purposive. Pengukuran pada kedua kelompok ini masing-masing dua kali, pada kelompok ekperimen dilakukan sebelum dan sesudah intervensi diberikan sedangkan pada kelompok kontrol juga dilakukan dua kali 
pengukuran tanpa pemberian treatment (Gravetter dan Forzano, 2015).

\section{Partisipan}

Penelitian tidak dilakukan pada segenap objek dari populasi, tetapi cukup sebagian yang dipandang mewakili populasi (Marliani, 2013). Adapun teknik pengambilan sampel yang dilakukan adalah non-random sampling yakni purposive sampling. Adapun jumlah partisipan dalam penelitian ini sebanyak 35 siswa, terdiri dari dua kelompok yaitu 19 siswa kelompok eksperimen yang berasal dari sekolah "A" dan 16 siswa kelompok kontrol yang berasal dari sekolah "B". Adapun kriteria subjek yaitu siswa kelas II Sekolah Dasar, berusia 7-8 tahun, mampu membaca abjad bahasa Inggris, dan memiliki intelegensi rata-rata, menggunakan standar kategori tes inteligensi CFIT.

\section{Metode Pengumpulan Data}

Screening (observasi). Observasi dilakukan di kelas bagi siswa dan guru kelas II Sekolah Dasar untuk mengetahui kemampuan dan metode yang digunakan dalam pembelajaran pada mata pelajaran bahasa Inggris. Selama proses pembelajaran yang dilakukan guru memberikan ceramah atau penjelasan secara lisan mengenai materi, lalu disertai dengan penyelesaian LKS sebagai latihan soal yang harus dikumpulkan di akhir pelajaran. Guru memberikan kesempatan pada siswa untuk mengerjakan latihan soal selama 30 menit, dan memberikan kesempatan untuk berdiskusi jika ada persoalan yang tidak dimengerti oleh siswa.

Screening (wawancara). Wawancara merupakan teknik pengumpulan data yang dilakukan melalui tatap muka dan tanya jawab langsung antara pengumpul data maupun peneliti terhadap narasumber atau sumber data dengan menggunakan panduan wawancara. Wawancara dilakukan pada guru kelas, terkait dengan metode pembelajaran di kelas.
Tes intelegensi. Screening yang dilakukan adalah tes intelegensi dengan menggunakan alat tes intelegensi CFIT Skala-2 (Culture Fair Intelligence Test Scale-2). CFIT mengukur kemampuan mental umum atau faktor "g" dari Spearman. Dari skor mentah dapat ditemukan IQ dan persentil dengan tabel yang sudah disediakan. Tes ini diberikan pada siswa kelas II SD.

Tes alfabet bahasa Inggris. Tes alfabet bahasa Inggris untuk mengetahui pengetahuan siswa terhadap alfabet bahasa Inggris, dengan cara menyajikan alfabet A-Z dan meminta siswa-siswa tersebut menyebutkannya. Tes ini diberikan pada siswa kelas II SD.

\section{Pengukuran}

Alat ukur yang digunakan dalam penelitian ini berupa soal mencocokkan gambar dan kata atau matching test, terdiri dari 18 buah soal yang mewakili sejumlah flash cards yang diberikan.

\section{Manipulasi}

Flash Cards diberikan selama jam pelajaran bahasa Inggris selama 5 sesi dengan alokasi waktu 35 menit setiap sesinya. Manipulasi yang dilakukan adalah pemberian kosakata mengenai part of body, vegetables, transportation, animals, dan dining room. Pemberian materi disesuaikan dengan silabus yang telah ditetapkan untuk siswa kelas II Sekolah Dasar. Adapun setiap sesi dari manipulasi yang dilakukan adalah pembukaan, pengenalan kata dan games bagi siswa.

Tahapan dari manipulasi yang dilakukan; (1) Siapkan 10 kartu dari kelompok yang sama, misalnya kelompok "animals", ditumpuk dan dipegang dengan tangan kiri. Halaman kartu yang bergambar berada di bagian depan menghadap ke siswa. (2) Untuk menarik perhatian siswa (untuk tahap awal), tunjukkan halaman kartu yang bergambar dengan cara mengambil kartu yang paling belakang dan meletakkannya ke urutan paling depan, 
sambil mengucapkan dengan jelas kata tersebut, misalnya "caterpillar".

Kemudian baliklah gambar caterpillar tersebut sehingga tulisan "ulat bulu" berada di bagian depan, sambil mengucapkan "caterpillar". (4) Minta siswa untuk mengikuti/ mengulang menyebutkan caterpillar sebanyak 3 kali. (5) Ulangi secara berurutan hingga kartu kesepuluh.

\section{Validitas Instrumen}

Uji validitas yang digunakan dalam penelitian ini adalah uji validitas isi (content validity). Untuk instrumen yang berbentuk tes, pengujian validitas isi dapat dilakukan dengan membandingkan antara isi instrumen dengan materi pelajaran yang telah diajarkan. Secara teknis pengujian validitas isi dapat dibantu dengan menggunakan kisi-kisi instrumen, atau menarik pengembangan instrumen (Sugiyono, 2010).

Validasi Modul dan Alat Ukur. Langkah yang dilakukan peneliti dalam mempersiapkan modul dan alat ukur, yaitu menentukan tema flash cards yang akan diberikan kepada siswa sesuai dengan silabus siswa kelas II Sekolah Dasar yaitu: part of body, vegetables, transportation, animals, dan dining room; Menentukan jumlah soal yang dapat mewakili setiap tema yang akan diberikan. Menyusun langkah penyajian media; Melakukan validasi (professional judgement) dengan ahli dalam bidang Psikologi Eksperimen dan Psikologi Pendidikan tentang alat ukur dan modul, untuk memberikan masukan demi kesempurnaan modul.

Uji Coba Modul. Uji coba modul diberikan pada siswa kelas II, uji coba modul dilakukan bertujuan untuk melihat efisiensi waktu yang telah ditetapkan, serta menguji coba apakah langkah penggunaan media yang telah disusun dapat dipahami oleh tutor sehingga media dapat digunakan dengan tepat. Uji coba ini dilakukan sebagai coaching bagi guru selama pelaksanaan manipulasi. Uji coba ini dilakukan untuk mengetahui kesamaan pengetahuan dan kemampuan guru ketika melaksanakan program. Kejelasan instruksi ketika pelaksanaan metode flash cards di dalam kelas, waktu yang digunakan untuk 10 kartu yang akan dijelaskan.

Waktu yang digunakan untuk mengulang kartu sebanyak 3 kali. Awalnya pengulangan ini dilakukan sebanyak 6 kali, namun atas saran dari guru yang mengajarkan akan memunculkan kebosanan siswa, maka pengulangan cukup dilakukan 3 kali untuk setiap kartu yang dibacakan/ dijelaskan. Guru diminta untuk membaca flash cards secara jelas dan volume yang cukup keras, sehingga dapat didengar oleh seluruh siswa di dalam kelas. Uji coba ini dilakukan untuk mengetahui total waktu yang digunakan setiap sesinya. Estimasi waktu yang digunakan sebelum uji coba modul 50 menit/ sesi, namun pada saat uji coba modul terlalu lama dan panjang ketika pelaksanaan di kelas, sehingga menjadi 35 menit.

\section{Reliabilitas}

Reliabilitas adalah penerjemahan dari kata reliability yang artinya keterpercayaan, keterdalaman, keajegan, kestabilan, konsistensi, namun ide pokok yang terkandung dalam konsep reliabilitas adalah sejauhmana hasil suatu pengukuran dapat dipercaya (Azwar, 2009). Pengukuran yang memiliki reliabilitas tinggi disebut pengukuran reliabel.

\section{Teknik Analisis Data}

Analisis data merupakan salah satu cara untuk memecahkan masalah penelitian. Meng-gunakan analisis data dapat menjawab dan menguji hipotesis (Nazir, 2003). Analisis data penelitian ini menggunakan independent t-test, independent t-test digunakan untuk membandingkan dua kelompok yang saling bebas atau tidak terikat satu sama lain. Untuk dapat dianalisis menggunakan independent t-test data penelitian harus memenuhi beberapa asumsi, yaitu: subjek > 30, data normal dan varians homogen 
(Sapp, 1999). Analisis dalam penelitian dilakukan menggunakan bantuan komputerisasi software statistic untuk melihat bagaimana efektifitas flash cards (X) untuk meningkatkan kosakata (Y).

\section{Teknik Uji Normalitas dan Homogenitas}

Uji Normalitas. Uji normalitas bertujuan untuk melihat sebaran data yang akan dianalisis berdistribusi normal atau tidak. Dalam penelitian ini uji normalitas dilakukan terhadap kelompok eksperimen dan kelompok kontrol.

Tabel 1

Hasil uji normalitas data $N$-Gain

\begin{tabular}{|c|c|c|c|c|c|c|c|}
\hline & \multirow{2}{*}{$\begin{array}{l}\text { Kelom- } \\
\text { pok }\end{array}$} & \multicolumn{3}{|c|}{$\begin{array}{c}\text { Kolmogorov- } \\
\text { Smirnov }^{\mathrm{a}}\end{array}$} & \multicolumn{3}{|c|}{ Shapiro-Wilk } \\
\hline & & Stat. & $\mathrm{df}$ & Sig. & Stat. & $\mathrm{df}$ & Sig. \\
\hline \multirow[t]{2}{*}{$\begin{array}{l}G a \\
-i n\end{array}$} & $\begin{array}{l}\text { Eksperi } \\
\text {-men }\end{array}$ & .137 & 19 & $.200^{*}$ & .941 & 19 & .273 \\
\hline & Kontrol & .173 & 16 & $.200^{*}$ & .961 & 16 & .674 \\
\hline
\end{tabular}

Berdasarkan tabel 1 diperoleh hasil analisis shapiro-wilk $\mathrm{p}=0.273$ pada kelompok eksperimen dan $\mathrm{p}=0.674$ pada kelompok kontrol. Pada penelitian ini probabilitas $(\alpha)$ 0.01. Nilai p lebih besar dari 0.01 dapat dinyatakan bahwa $\mathrm{H}_{0}$ diterima, artinya adalah bahwa sebaran data $\mathrm{N}$-Gain berdistribusi normal.

Uji Homogenitas. Uji homogenitas dilakukan untuk melihat apakah perbandingan varians antar kelompok sama atau tidak atau apakah kelompok berasal dari populasi yang memiliki varians yang sama atau tidak.

Tabel 2

Uji homogenitas N-Gain

\begin{tabular}{llcc}
\hline & & \multicolumn{2}{c}{$\begin{array}{c}\text { Levene's Test for } \\
\text { Equality of Variances }\end{array}$} \\
\cline { 3 - 4 } Gain & $\begin{array}{l}\text { Equal variances } \\
\text { assumed }\end{array}$ & 2.605 & Sig. \\
\hline & $\begin{array}{l}\text { Equal variances } \\
\text { not assumed }\end{array}$ & & \\
\hline
\end{tabular}

Levene's Test for Equality of Variances digunakan untuk menguji asumsi homogenitas varians. Berdasarkan tabel 2 nilai $\mathrm{F}$ yang diperoleh adalah 2.605 dengan nilai Sig. (p) 0.116 (p > 0.01). karena nilai signifikansi lebih besar dari 0.01 hal ini menyatakan bahwa $\mathrm{H}_{0}$ diterima, yang artinya bahwa kedua kelompok merupakan varians yang homogen. Berdasarkan hasil analisis tersebut, maka data yang digunakan untuk melihat nilai t-hitung yaitu data pada equal variances assumed.

\section{Hasil Penelitian dan Pembahasan}

\section{Hasil Penelitian}

Uji Hipotesis. Tujuan dilakukannya analisis data adalah untuk menjawab dan menguji hipotesis. Analisis data penelitian ini menggunakan independent t-test, independent t-test digunakan untuk membandingkan dua kelompok yang saling bebas atau tidak terikat satu sama lain.

\section{Tabel 3}

Rerata gain score kelompok eksperimen dan kontrol

\begin{tabular}{llrll}
\hline & Group & $\mathrm{N}$ & Mean & $\begin{array}{c}\text { Std. } \\
\text { Deviation }\end{array}$ \\
\hline \multirow{2}{*}{ Gain } & Ekperimen & 19 & 11.7895 & 3.32631 \\
& Kontrol & 16 & 3.2500 & 1.98326 \\
\hline
\end{tabular}

Dapat dilihat pada tabel 3 rerata kelompok eksperimen $(\mathrm{M}=11.7895)$ lebih tinggi daripada rerata kelompok kontrol $(\mathrm{M}=3.2500)$. Artinya terdapat perbedaan yang signifikan antara rerata kelompok eksperimen dan kelompok kontrol.

Tabel 4

Hasil Uji-t

\begin{tabular}{ccccc}
\hline Data & T & df & $\begin{array}{c}\text { Sig. (2- } \\
\text { tailed) }\end{array}$ & $\alpha$ \\
\hline $\begin{array}{c}\text { Equal } \\
\text { variances } \\
\text { assumed }\end{array}$ & $\mathbf{8 . 9 9 8}$ & 33 & $\mathbf{0 . 0 0 0}$ & $\mathbf{0 . 0 1}$ \\
\hline
\end{tabular}

Pada tabel 4 menunjukkan nilai t- hitung 8.998 dengan signifikansi 0.000 $(\mathrm{p}<0.01)$, artinya adalah terdapat perbedaan yang signifikan antara hasil posttest 
kelompok eksperimen dan kelompok kontrol. Untuk mengetahui signifikansinya maka perlu dibandingkan dengan nilai t-tabel. Nilai t-tabel untuk derajat bebas 33 $(\mathrm{df}=35-2)$ adalah 2,7332. Nilai t-hitung lebih besar dari pada nilai t-tabel, maka dapat dinyatakan bahwa flash cards dapat meningkatkan kemampuan kosakata bahasa Inggris siswa.

Deskripsi Analisis Data. Analisis data menggunakan independent t-test dengan bantuan komputerisasi software statistic bertujuan untuk melihat rerata gain score pada kedua kelompok penelitian yaitu kelompok eksperimen dan kelompok kontrol serta melihat nilai $\mathrm{F}$ dan $\mathrm{t}$ yang dapat menentukan bahwa penelitian tersebut homogen dan terdapat perbedaan yang signifikan pada kedua kelompok penelitian. Nilai F sebesar 2.605 dengan signifikansi 0.116. Berdasarkan ketentuan hipotesis apabila signifikansi lebih besar dari 0.01 menandakan bahwa penelitian tersebut bersifat homogen, maksudnya adalah tidak ada varians antara kedua kelompok penelitian. Diketahui bahwa hasil penelitian bersifat homogen maka nilai $\mathrm{t}$ dan signifikansi yang digunakan merupakan nilai pada data equal variances assumed, nilai t 8.998 dan signifikansi 0.000 . Berdasarkan ketentuan apabila nilai signifikansi pada $\mathrm{t}$ lebih kecil dari nilai probabilitas $(\alpha) 0.01$ berarti hasil dari kedua kelompok penelitian terdapat perbedaan yang signifikan. Perbedaan signifikan tersebut dapat dilihat pada rerata gain skor kelompok eksperimen $(\mathrm{M}=11.7895)$ lebih tinggi dibandingkan kelompok kontrol $(\mathrm{M}=3.2500)$.

Deskripsi Kategorisasi Subjek. Skor dalam suatu penelitian belum memberikan gambaran yang jelas mengenai subjek yang diteliti untuk memiliki makna yang memiliki nilai diagnostik. Sisi diagnostika suatu pengukuran atribut psikologi adalah pemberian makna atau interpretasi terhadap skor skala yang bersangkutan. Sebagai suatu hasil ukur angka (kuantitatif), skor skala memerlukan suatu norma pembanding agar dapat diinterpretasikan secara kuantitatif. Interpretasi skala psikologi selalu bersifat normatif, artinya makna skor dicantumkan pada posisi relatif skor dalam suatu kelompok yang telah dibatasi terlebih dahulu (Azwar, 2009).

Kelompok eksperimen terdapat 19 subjek dan kelompok kontrol 16 subjek, untuk kategorisasi data kedua kelompok menggunakan N-Gain. Untuk kelompok eksperimen Mean $=0.5(17+5)=11$, standar deviasi $=1 / 6(17-5)=2$, untuk kelompok kontrol Mean $=0.5(7+0)=3.5$, standar deviasi $=1 / 6(7-0)=1.17$. gambaran hipotesis $\mathrm{N}-$ Gain dapat dilihat pada tabel 5.

Tabel 5

Gambaran Hipotesis N-Gain

\begin{tabular}{lccccc}
\hline \multicolumn{1}{c}{ Data } & $\mathrm{N}$ & Mean $(\mu)$ & Max & Min & $\begin{array}{c}\text { Standar } \\
\text { Deviasi } \\
(\sigma)\end{array}$ \\
\hline $\begin{array}{l}\text { Gain } \\
\text { eksperimen }\end{array}$ & 19 & 11 & 17 & 5 & 2 \\
$\begin{array}{l}\text { Gain kontrol } \\
\text { Gain }\end{array}$ & 16 & 3.5 & 7 & 0 & 1.17 \\
\hline
\end{tabular}

Berdasarkan tabel 5 diperoleh ketentuan sebagai berikut: $\mathrm{X}<(\mu-1,0 \sigma)$ untuk kategori rendah, $(\mu-1,0 \sigma) \leq \mathrm{X}<$ $(\mu+1,0 \sigma)$ untuk kategori sedang dan $(\mu+1,0 \sigma) \leq X$ untuk kategori tinggi.

Dapat dilihat pada tabel 6 bahwa persentase yang mencapai gain skor rendah $16 \%$ dengan range nilai $X<9$, gain skor sedang 37\% dengan range nilai $9 \leq X<13$ dan gain skor tinggi $47 \%$ dengan range nilai $13 \leq \mathrm{X}$. Artinya hasil penelitian menunjukkan adanya peningkatan nilai yang signifikan karena terdapat $84 \%$ siswa yang mampu mencapai nilai di atas kategorisasi rendah.

Tabel 6

Kategorisasi N-Gain kelompok eksperimen

\begin{tabular}{cccc}
\hline Kategori & Nilai & Frekuensi & $\begin{array}{c}\text { Persentase } \\
(\%)\end{array}$ \\
\hline Rendah & $\mathrm{X}<9$ & 3 & $16 \%$ \\
Sedang & $9 \leq \mathrm{X}<$ & 7 & $37 \%$ \\
Tinggi & 13 & 9 & $47 \%$ \\
& $13 \leq \mathrm{X}$ & 9 & $100 \%$ \\
\hline & Total & 19 &
\end{tabular}


Tabel 7

Kategorisasi N-Gain kelompok kontrol

\begin{tabular}{cccc}
\hline Kategori & Nilai & Frekuensi & $\begin{array}{c}\text { Persentase } \\
(\%)\end{array}$ \\
\hline Rendah & $\mathrm{X}<2.33$ & 7 & $44 \%$ \\
Sedang & $2.33<\mathrm{X}$ & 4 & $25 \%$ \\
Tinggi & $<4.67$ & & \\
& $4.67<\mathrm{X}$ & 5 & $31 \%$ \\
& Total & 16 & $100 \%$ \\
\hline
\end{tabular}

Pada kelompok kontrol dapat dilihat pada tabel 7 , persentase gain skor rendah $44 \%$ dengan range nilai $\mathrm{X}<2.33$, persentase gain skor sedang $25 \%$ dengan range nilai $2.33 \leq \mathrm{X}<4.67$ dan persentase gain skor tinggi $31 \%$ dengan range nilai $4.67 \leq X$. Artinya tidak ada peningkatan nilai yang signifikan pada kelompok kontrol karena masih terdapat $44 \%$ siswa yang mendapatkan nilai rendah.

\section{Pembahasan}

Berdasarkan hasil penelitian yang diperoleh bahwa flash cards dapat meningkatkan kemampuan kosakata bahasa Inggris siswa, perubahan tersebut dapat dilihat dari hasil pretest-posttest siswa. Subjek kelompok eksperimen menunjukkan hasil yang lebih baik daripada kelompok kontrol. Subjek eksperimen memperoleh peningkatan yang signifikan yang dapat dilihat pada perolehan rerata gain score yang lebih tinggi dibandingkan kelompok kontrol. Perlakuan pada kelompok eksperimen diberikan selama lima sesi pertemuan, yaitu setiap sesi pertemuan diberikan tema yang berbeda sesuai dengan silabus. Adapun tema yang diberikan dalam setiap sesi yaitu part of body, vegetables, transportation, animals, dan dining room. Sedangkan pada kelompok kontrol tidak diberikan perlakuan, mereka menggunakan metode konvensional yaitu metode biasa yang digunakan oleh guru dengan ceramah dan latihan soal dalam menyelesaikan LKS. Hal ini bertujuan untuk melihat perubahan yang diperoleh oleh kelompok eksperimen dengan menjadikan kelompok kontrol sebagai pembanding keberhasilan penelitian.
Menurut Piaget, tingkat pemahaman siswa Sekolah Dasar awal mengenai konsep tentang benda, nama, jenis binatang dan pemahaman jenis konsep lainnya tidak dapat dilakukan hanya melalui membaca dan mendengarkan penjelasan guru (Surna dan Pandeirot, 2002). Anak-anak memerlukan bantuan orang yang lebih ahli agar mereka dapat menyelesaikan tugas mereka dengan cara yang tepat yang disebut sebagai ZPD (Zone of Proximal Development) oleh Vygotsky. Berdasarkan pandangan itu maka diperlukan benda yang nyata atau hal yang berbentuk visual untuk mengetahui dan mengenal konsep-konsep yang dipelajari. Metode yang tepat untuk mengajarkan kosakata baru adalah dengan menggunakan alat peraga yang menarik, sehingga siswa dapat dengan mudah mengenal kosakata baru tersebut. Flash cards merupakan alat bantu bagi siswa untuk mempelajari kosakata dan memahami konsep yang dipelajari, yang dapat mempermudah siswa menyelesaikan tugasnya yaitu mampu mencapai tuntutan kurikulum, dan bantuan tersebut dinamakan scaffolding oleh Vygotsky (dalam Ormrod, 2008).

Belajar menggunakan media flash cards dapat membantu subjek menghafal serta mengingat dengan cepat kata-kata yang telah mereka pelajari. Selain efektif meningkatkan kosakata, flash cards juga dapat memotivasi dan membuat siswa tertarik untuk belajar (Joklova, 2009). Mereka memperhatikan dengan seksama guru yang ada di depan dan fokus pada flash cards yang diberikan, mereka juga antusias untuk menunjuk tangan ketika diberikan pertanyaan mengenai kata-kata tersebut. Brown (2008) mengutarakan flash cards juga dapat membuat suasana belajar menjadi lebih menarik, guru dapat menciptakan suasana belajar yang lebih hidup dan meningkatkan antusias anakanak dalam mempelajari bahasa Inggris, karena hal ini dapat dilakukan dengan cara bermain. Bermain sambil belajar menggunakan media flash cards akan 
memengaruhi afektif siswa yang mana akan memengaruhi keberhasilan mempelajari kata (Brown, 2008). Belajar sambil bermain tersebut juga membuat suasana kelas menjadi santai, hal tersebut terlihat dari keinginan siswa untuk tampil ke depan guna menunjukkan kemampuan hafalan mereka.

Flash cards dapat membantu siswa dalam mengenal kata-kata baru dan juga membantu siswa mengenal benda-benda baru dari gambar yang terdapat pada flash cards tersebut (Nugroho dkk., 2012). Hal yang sangat memengaruhi daya ingat siswa ketika gambar tersebut ada dalam bentuk konkretnya, yaitu mengenai body. Siswa tersebut mencoba merecall kembali kata finger dengan menggerak-gerakkan telunjuknya, karena pada flash cards kata finger digambarkan dengan telunjuk. Hal tersebut menunjukkan bahwa gambar memberikan kode lain yang bersifat independen dari kode verbal (Pavio dalam Stephen, 2011). Flash cards disajikan secara acak oleh guru, guru membimbing siswa mengucapkan bahasa Inggris dan arti dari kata yang ada pada flash cards, hal tersebut diulang sebanyak tiga kali.

Menurut Brown (2008) flash cards disajikan dengan cara berulang-ulang dan menirukan berulang-ulang merupakan strategi yang sangat penting dalam pembelajaran bahasa. Pengulangan tersebut dapat membantu siswa untuk menyimpan informasi verbal tersebut dalam memori jangka pendek atau mentransfernya kedalam memori jangka panjang (Stenberg, 2008). Menurut Nation (dalam Schmitt dan Schmitt, 1995) bahwa untuk mempelajari kata baru, siswa butuh melakukan pengulangan sebanyak 3-10 kali atau lebih. Flash cards yang sering diulang-ulang penyebutannya secara serempak bersama guru, akan membantu siswa mengingat kata tersebut lebih cepat, pengulangan tersebut dapat membuat siswa fokus terhadap apa yang dipelajari (Joklova, 2009). Cohen (dalam Schmitt dan Schmitt, 1995) berpendapat bahwa keberhasilan mempe- lajari sesuatu ditentukan oleh fokus seseorang terhadap apa yang sedang dipelajari.

Ketika siswa diberikan materi mengenai animals dan dining room yang mana hal tersebut tidak ada bentuk konkretmya seperti part of body. Siswa memperhatikan gambar yang ada di depan dan mendengarkan guru mengucapkan kata tersebut dengan tepat, semula siswa yang tidak bisa menyebutkan kata dengan benar, karena proses pengulangan dan adanya konfirmasi dari guru mengenai pengucapan yang tepat membuat siswa mampu dan dapat menyebut bahasa Inggris dan arti kata dengan benar. Dalam proses belajar yang diulang yang disimpan dalam memori di dalamnya terjadi pengkodean yaitu menempatkan informasi agar dapat dengan mudah diingat (Stenberg, 2008). Hudson dkk. (dalam Carpenter dan Olson, 2011) mengutarakan gambar yang terdapat pada flash cards tersebut akan membantu meningkatkan daya ingat anak-anak, karena visual memberikan pengaruh yang lebih besar dalam mengingat dan memahami sesuatu dibandingkan verbal/ audio. Hal tersebut memengaruhi siswa, siswa menjadi cepat mengenal dan memahami kata yang dipelajari serta dapat dengan mudah merecall kembali informasi yang telah diterima siswa yaitu sejumlah kosakata yang telah dikenalkan dengan flash cards.

Untuk mempelajari bahasa tidak hanya didasari oleh pertimbangan kognitif, tetapi aspek afektif juga memengaruhi keberhasilan mempelajari bahasa, wilayah afektif meliputi banyak faktor seperti sikap, peniruan, kecemasan, empati dan kepercayaan diri (Brown, 2008). Komachali dan Khodareza (2012) juga mengutarakan hal yang serupa flash cards dapat meningkatkan perhatian, partisipasi, interaksi, dan semangat siswa dalam mempelajari kosa-kata baru. Daya tarik tersebut terlihat dari antusias dan partipasi siswa saat belajar berlangsung, yaitu ketika siswa diminta maju berpasang-pasangan menggunakan media flash cards untuk 
menunjukkan kemampuan mereka menyebutkan kembali arti kata yang telah mereka pelajari.

Selain dapat membantu daya ingat siswa, flash cards juga dapat memberikan dampak yang lain yaitu dapat memotivasi dan membuat siswa tertarik untuk belajar (Joklova, 2009). Motivasi yang mereka miliki tersebut juga membantu daya ingat siswa dalam menghafal kata tersebut, karena mereka belajar berdasarkan keinginan mereka (Komachali dan Khodareza, 2012). Belajar bersama-sama dengan flash cards juga membuat siswa termotivasi untuk menghafal kata dengan cepat, dengan itu mereka dapat memperlihatkan kepada teman-teman sekelas mereka kemampuan mereka dengan cara dapat menjawab pertanyaan guru dengan cepat dan benar (Joklova, 2009). Menggunakan media flash cards untuk mempelajari kosakata baru dapat membuat siswa berinteraksi satu dengan yang lainnya selama proses belajar. Interaksi tersebut dapat membantu siswa satu sama lain untuk berbagi pengetahuan mengenai kosakata yang telah mereka hafal dan ketahui (Komachali dan Khodareza, 2012).

Media flash cards dapat meningkatkan kemampuan kosakata bahasa Inggris siswa pada mata pelajaran bahasa Inggris, adanya peningkatan jumlah kosakata yang dimiliki oleh siswa kelas II SDN di Pekanbaru. Kelompok eksperimen yang mendapatkan perlakukan melalui media flash cards, terdapat 12 siswa yang mendapat skor sempurna yaitu 18, 2 siswa yang mendapat skor 16, 2 siswa yang mendapat skor 15,1 siswa mendapat skor 14, 1 siswa mendapat skor 12 dan 1 siswa mendapat skor 10 . Hal tersebut menunjukkan peningkatan yang signifikan dari pretest yang dilakukan sebelumnya. Adapun persentase yang mencapai gain skor rendah $16 \%$ dengan range nilai $\mathrm{X}<9$, gain skor sedang $37 \%$ dengan range nilai $9 \leq \mathrm{X}$ $<13$ dan gain skor tinggi $47 \%$ dengan range nilai $13 \leq \mathrm{X}$. Artinya hasil penelitian menunjukkan adanya peningkatan nilai yang signifikan karena terdapat $84 \%$ siswa yang mengalami peningkatan kosakata bahasa Inggris.

Hal ini senada dengan penelitian yang telah dilakukan oleh Maghfiroh dan Zuhdi (2013) disimpulkan bahwa aktivitas guru dan siswa dalam proses pembelajaran tematik tema pekerjaan dengan menggunakan media flash card dinyatakan baik sekali. Hasil belajar siswa setelah penggunaan media flash card pada tema pekerjaan dinyatakan baik sekali. Hal ini menunjukkan bahwa media flash card dapat meningkatkan hasil belajar siswa. Selain itu, penelitian yang dilakukan oleh Widyasari, Suryandari dan Suripto (2013) bahwa penerapan metode permainan melalui media flash card dapat meningkatkan kemampuan kosakata bahasa Inggris siswa kelas IV SDN 2 Kebasen Kecamatan Kebasen tahun ajaran 2012/ 2013. Peningkatan kemampuan kosakata bahasa Inggris ini ditunjukkan dengan adanya peningkatan pada aspek keterampilan berbahasa dan hasil belajar siswa.

Menurut Komachali dan Khodareza (2012) dengan flash cards siswa dapat belajar tanya jawab seputar kosakata, harihari bersejarah, rumus dan mata pelajaran lainnya. Hal itu dapat dilakukan secara berulang sehingga membuat flash cards membantu siswa mengingat apa yang telah dipelajari. Flash cards adalah media yang praktis untuk membantu siswa dan guru dalam proses belajar mengajar, khususnya dalam mengajarkan siswa flash cards (Nugroho dkk., 2012). Dengan media flash cards dapat dengan mudah membantu siswa merecall kosakata baru yang sedang dipelajari, karena flash cards memiliki dua sisi yaitu kata dan artinya (Khodashenas dkk., 2014)

\section{Simpulan dan Saran}

\section{Simpulan}

Berdasarkan hasil penelitian yang telah dilakukan maka dapat disimpulkan bahwa flash cards berpengaruh signifikan untuk 
meningkatkan kemampuan kosakata bahasa Inggris siswa Sekolah Dasar. Flash cards dapat membantu siswa belajar lebih fokus dan dapat mengenal kata dengan mudah. Berdasarkan hasil observasi di lapangan, siswa menjadi sangat bersemangat dan antusias mempelajari kosakata. Flash cards dapat digunakan dengan berpasangpasangan sambil maju ke depan kelas, sehingga membuat siswa dapat belajar sambil bermain dan meningkatkan minat mereka untuk mempelajari kosakata. Menggunakan flash cards sebagai media belajar juga membuat siswa berani dan tidak malu untuk tampil ke depan kelas.

\section{Saran}

Bagi Sekolah. Sekolah diharapkan dapat memberikan metode yang bervariatif dalam mengajarkan kosakata bahasa Inggris kepada siswa, salah satunya dengan menggunakan media flash cards.

Bagi Tutor. Diharapkan tutor memahami penggunaan media dengan lugas, sehingga tujuan penggunaan media sesuai dengan hasil yang diharapkan.

Bagi Peneliti Selanjutnya. Peneliti selanjutnya diharapkan dapat menemukan metode-metode yang lainnya untuk dapat membantu siswa dalam meningkatkan kosakata pada bahasa Inggris. Adapun peneliti yang ingin mencoba melakukan penelitian yang sama, sebaiknya menghindari batasan-batasan penelitian yang menyebabkan bias, yaitu (1) Peneliti tidak melakukan sesi wawancara terhadap siswa yang mengikuti les bahasa Inggris, karena hal ini akan memengaruhi pengetahuan kosakata siswa yang akan menjadi bias dari hasil penelitian yang diperoleh. (2) Tutor pada penelitian ini tidak mempelajari metode penggunaan media flash cards terlebih dahulu, hal ini menyebabkan proses belajar di awal sangat kaku yang mana semestinya siswa dapat belajar dengan menyenangkan, karena rasa senang saat belajar akan memengaruhi siswa untuk fokus dan tertarik dalam belajar.

\section{Daftar Pustaka}

Azwar, S. (2009). Reliabilitas dan Validitas, Yogyakarta: Pustaka Pelajar.

Arsyad, A. (2011). Media Pembelajaran, Jakarta: Rajagrafindo Persada.

Baleghizadeh, S. \& Ashoori, A. (2011). The Impact of Two Instructional Tehniques on EFL Learner's Vocabulary Knowledge: Flash Cards Versus Word List, Mextesol journal, 35(2).

Brown, H.D. (2008). Prinsip Pembelajaran dan Pengajaran Bahasa, edisi kelima, Kedutaan Besar Amerika Serikat di Jakarta.

Campbell, D., Shadish, W.R., \& Cook, T.D. (2002). Experimental and Quasiexperimental Designs for Generalized Causal Inference, Boston: Houghton Mifflin Company.

Carpenter, S.K. \& Olson, K.M. (2011). Are Pictures Good for Learning New Vocabulary in A Foreign Language? Only if You Think They Are Not, Journal of Experimental Psychology: Learning, Memory, and Cognition.

Gravetter, F. \& Forzano, Lori-Ann. (2015). Research Methods for the Behavioral Sciences, fifht edition, USA: Nelson Education, Ltd.

Hotimah, E. (2010). Penggunaan Media Flashcard dalam Meningkatkan Kemampuan Siswa pada Pembelajaran Kosakata Bahasa Inggris Kelas II MI Ar-Rochman Samarang Garut, Jurnal Pendidikan, 04(01).

Joklova, K. (2009). Using Pictures in Teaching Vocabulary, Bachelor's thesis. Masaryk University Faculty of Education. Department of English Language and Literature. Brno.

Keswara, R. (13 Oktober 2012). Belajar Bahasa Inggris Masih Membosankan. Sindonews (Online), 
(http://nasional.sindonews.com).

Diunduh: 4 april 2015. Dari: http://nasional.sindonews.com/read/ 679341/15/belajar-bahasa-inggrismasih-membosankan-1350053017.

Khasanah, P.M.A., Chamdani, \& Susiani, T.S. (2014). Upaya Meningkatkan Penguasaan Kosakata Bahasa Inggris melalui Penggunaan Media Kartu Domino Kata Bergambar Siswa Kelas V SD, PGSD FKIP Universitas Sebelas Maret Surakarta, 2(4).

Khodashenas. M.R., Farahani. S.K., \& Alisahi, Z. (2014). Flash Cards Versus Animated Cartoons: a Comparative Study in Vocabulary Teaching and Learning, International Journal of Language Learning and Applied Linguistics World (IJJLLALW), 5(4).

Komachali, M.E. \& Khodareza, M. (2012). International Education Studies the Effect of Using Vocabulary Flash Card on Iranian Pre-University Students Vocabulary Knowledge, International Education Studies, $5(3)$.

Listyarti, R. (13 november 2012). Sekali Lagi Ditegaskan, Bahasa Inggris SD Tak Dihapus. Kompas (online). (http://edukasi.kompas.com/).

Diunduh 30 maret 2015. Dari : http://edukasi.kompas.com/read/201 2/11/13/11331821/Sekali.Lagi.Dite gaskan.Bahasa.Inggris.SD.Tak.Diha pus

Maghfiroh, L. \& Zuhdi, U. (2013). Penggunaan Media Flashcard untuk Meningkatkan Hasil Belajar IPS pada Pembelajaran Tematik di Sekolah Dasar, JPGSD, 01(2).

Mohammadnejad, S., Nikdel, H., \& Oroujlou, N. (2012). Reactivating EFL Learners' Word Knowledge by Means of Two Technique: Flashcards versus Wordlist, International Journal of Linguistic, 4(4).
Marliani, R. (2013). Psikologi Eksperimen, Bandung: Pustaka Setia.

Nazir, M. (2003). Metode Penelitian, Jakarta: Salemba.

Nugroho, Y.S., Nurkamto, J., \& Sulistyowati, H. (2012). Improving Students' Vocabulary Mastery Using Flash Cards, English Education Journal, 1(1).

Ormrod. J.E. (2008). Psikologi Pendidikan Membantu Siswa Tumbuh dan Berkembang Edisi Keenam Jilid 1, Jakarta: Erlangga.

Oxford Learner's Pocket Dictionary. (2008). China: Oxford University.

Permendiknas (2006). Peraturan Menteri Pendidikan Nasional No. 22 tahun 2016.

Press. Peraturan Menteri Pendidikan Nasional Republik Indonesia No 23 Tahun 2006 menetapkan Standar Kompetensi Lulusan (SKL) untuk Satuan Pendidikan Dasar dan Menengah. Badan Standar Nasional Pendidikan. Diunduh: 28 maret 2015. Dari: (http://bsnpindonesia.org/id/wpcontent/uploads/2009/04/SKL_MA PEL_SD_MI.pdf)

Stephen, K.R. (2011). Kognisi Teori dan Aplikasi, Jakarta: Salemba Humanika.

Santrock. J.W. (2007). Perkembangan Anak Edisi Kesebelas Jilid 1, Jakarta: Erlangga. (2010). Psikologi Pendidikan Edisi Kedua, Jakarta: Salemba Humanika.

Sadirman, A.S., Rahardjo, R., \& Haryono, A. (2009). Media Pendidikan, Jakarta: Rajagrafindo Persada.

Sapp, M. (1999). Test Anxiety: Applied Research, Assesment, and Treatment Intervention, Boston: University Press of America.

Stenberg, R.J. (2008). Psikologi Kognitif Edisi Keempat, Yogyakarta: Pustaka Pelajar. 
Surna, I Nyoman. \& Pandeirot. O.D. (2002). Psikologi Pendidikan 1, Jakarta: Erlangga.

Sugiyono. (2010). Metode Penelitian

Kuantitatif Kualitatif \& RND, Bandung: Alfabeta.

Suyanto, K.K.E. (2010). English for Young Learners, Jakarta: Bumi Aksara.

Schmitt, N. \& Schmitt, D. (1995). Vocabulary Notebooks: Theoretical Underpinnings and Practical Suggestions.(133-143).

Widyasari, I., Suryandari, K.C., \& Suripto. (2013). Penerapan Metode Permainan melalui Media Flash Card dalam Peningkatan Kemampuan Kosakata Bahasa Inggris Siswa Kelas IV SDN 2 Kebasen, JPGSD, 01(1). 